EKONOMIA I FINANSE

DOI: $10.18276 /$ sip.2019.55-05

\author{
Iwona Markowicz*
}

Pawel Baran**

Uniwersytet Szczeciński

\title{
ASYMMETRIES IN MIRROR DATA ON POLISH INTRA-COMMUNITY SUPPLIES - CHANGES OVER TIME
}

\begin{abstract}
Studies on trade between EU countries are based on data from the Intrastat system. Information on transactions is recorded on the basis of declarations of entities engaged in dispatch or acquisition of goods from the EU. The data is called mirror data because it is collected, on the one hand, as values of goods supplied and, on the other hand, as values of acquisition of goods. So mirror data should converge, but this is not the case. The subject of the survey are Polish intra-Community supplies by product groups. The aim of the article was to create rankings of $\mathrm{CN}$ commodity chapters of Polish intra-Community supplies in 2005, 2011 and 2017 and to compare them. Using the proposed measures of data discrepancies, the quality of statistical information on Poland's intra-Community trade in goods by CN chapters was assessed.
\end{abstract}

Keywords: Poland's intra-Community trade, $\mathrm{CN}$ chapters, quality of statistical data

* ORCID 0000-0003-1119-0789, E-mail: iwona.markowicz@usz.edu.pl

** ORCID 0000-0002-7687-4041, E-mail: pawel.baran@usz.edu.pl 


\section{Introduction}

The INTRASTAT system was introduced in the European Union as a tool for obtaining data on intra-Community trade in goods. The INTRASTAT statistical declaration replaced an earlier customs declaration (SAD) due to the elimination of customs borders between member states. It was introduced in the EU on January, 1st 1993 (Eurostat, 2017a), and on May, $1^{\text {st }} 2004$ in Poland (upon accession to the EU). The effect was to oblige entities trading with other member states to provide information on intra-Community trade in goods turnover volume and weight in the form of monthly declarations. In Poland collection, control and correction of data from INTRASTAT declarations concerning trade in goods within the EU is handled by the Intrastat Department of the Revenue Administration Regional Office in Szczecin. The collected data are initially processed and transmitted to the Central Statistical Office and then to Eurostat (Baran, Markowicz, 2018a).

Statistics on the international trade of goods measure the value and quantity of goods traded between EU Member States (known as intra-EU trade) and goods traded by Member States with non-member countries (known as extra-EU trade). These statistics are the official source of information about imports, exports and the trade balance in the EU, its Member States and the euro area (Eurostat, 2018).

The aim of the analysis was to create rankings of $\mathrm{CN}$ chapters of Polish intra-Community supplies in 2005, 2011, and 2017, and to compare them. Using the proposed measures of data discrepancies, the quality of statistical information on Poland's intra-Community trade in goods by $\mathrm{CN}$ chapters was assessed.

The study used data from the Comext database (Eurostat). The differences between, on the one hand, the declared values of supplies by Polish businesses to their partners in EU countries and, on the other hand, the declared values of acquisitions from Polish entities, declared by their counterparts in the EU, broken down by $\mathrm{CN}$ chapters, were examined. The differences between these values are partly due to the statistical thresholds adopted. Moreover, they reflect the quality of data collected by the statistical services of EU countries and transmitted to Eurostat.

\section{Intra-Community supplies from Poland}

Data on Polish trade in goods with EU countries are based on information from the Intrastat declarations, made by entities trading goods with other EU-member 
state based businesses. Data from Intrastat system and Extrastat data (trade with third countries, i.e. outside the EU), including estimates (turnover of exempted entities and entities which did not fulfil the reporting obligation) are provided by the Central Statistical Office and Eurostat (GUS, 2017).

The study on Poland's trade in goods with EU countries is included in the programme of official statistics. Its purpose is to provide information on the scale of imports and exports (often referred to as supplies and acquisitions) in terms of quantity and value according to the Combined Nomenclature $(\mathrm{CN})$ with countries belonging to the European Union. The study evaluates the scale of trade development, connections and level of Poland's involvement in the economy of the EU member states. The results of the survey are used to develop trends in development, commodity structure, main partners of trade with EU countries.

In foreign trade statistics, the comparability of data derived from official statistics of different countries is a priority, as emphasized in EU legal acts (Regulations, 2009 and 2004).

The literature highlights the importance of foreign trade in the development of economies of both developed and developing countries. This importance is emphasized in numerous economic theories: from Smith's concept of absolute costs or Ricardo's theory of comparative costs to contemporary foreign trade theories, such as the technology gap theory, according to which countries at a higher level of development and at a higher level of technological advancement can transfer technology to their partner countries through foreign trade. (Domiter, 2008; Misztal, 2010; Topolewski, 2014). The need for research into the quality of the data regarding foreign trade is also highlighted (Baran, Markowicz, 2018b; GUS, 2018).

The work by Drzewoszewska, Pietrzak and Wilk (2013) emphasizes the importance of the impact of the globalisation process on the volume of trade flows between countries. The authors argue that the physical distance between countries is no longer such a significant barrier to international trade. Long-term intensification of ties between countries is a proof of the progressing globalisation, an example of which in economic terms is the integration of countries within the European Union. Countries with a high level of GDP are characterized by greater imports and exports. On the other hand, an increase in the value of foreign trade may have an impact on GDP growth. Polish foreign trade turnover (total exports and imports) with EU countries in the years 2005-2017 grew steadily (Figure 1). A temporary decrease in both exports and imports of goods occurred in 2009, which was caused by the global crisis. 
Figure 1. Polish foreign trade turnover with EU countries in years 2005-2017; values in million EUR (imports by country of dispatch)

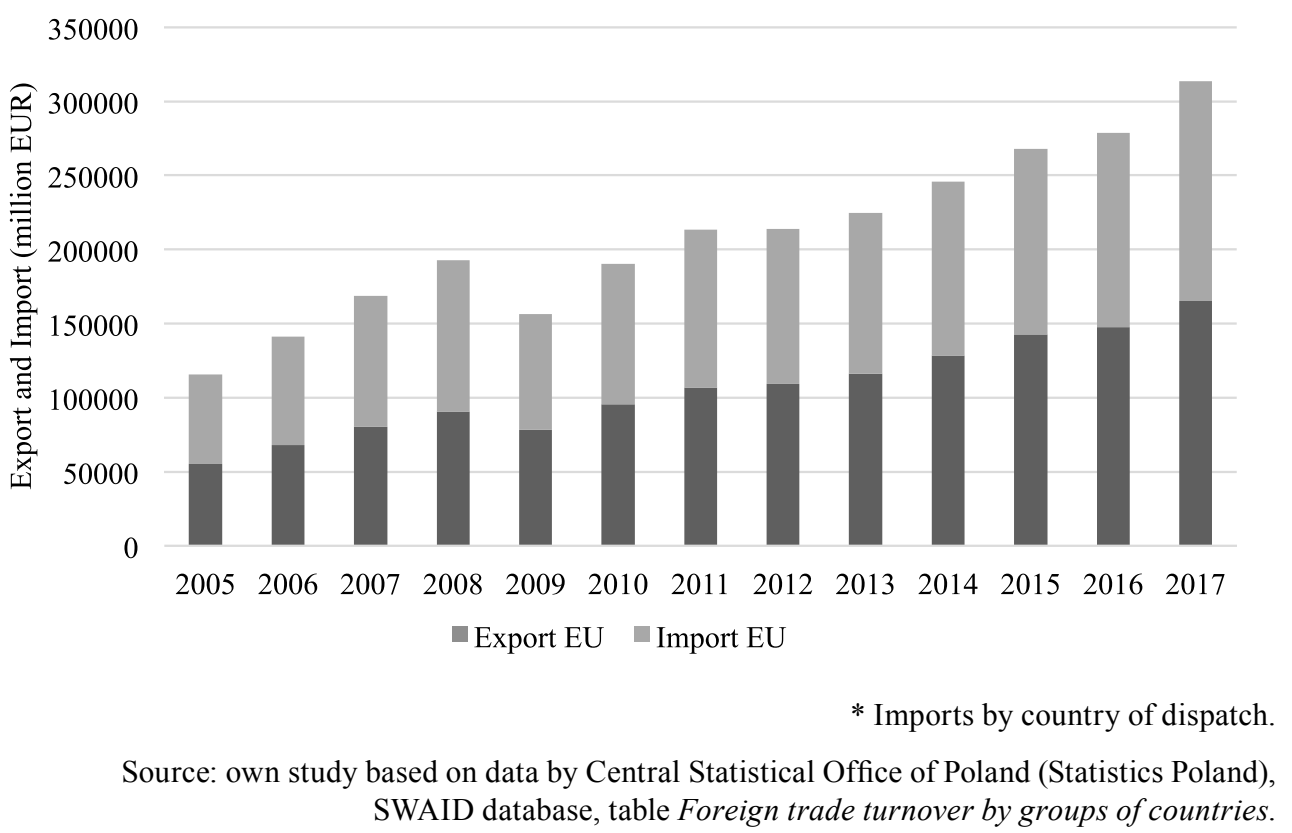

\section{Research methods}

The study used data on intra-Community supplies of goods from Poland to EU member states and its mirror data on intra-Community acquisitions. The analysis took into account the division of goods by $\mathrm{CN}$ chapters.

Mirror data (Baran, Markowicz, 2018a) for Poland and the EU (in CN chapter) should be understood as follows: it's the amount of goods declared by Poland-based business as dispatched from Poland to the EU-based trade partner, and its mirror acquisition of goods declared in the EU as originated from Poland.

Data from 2005, 2011 and 2017 were obtained from Eurostat's Comext database. The database is updated on an ongoing basis once the data have been collected by the national statistical offices. The analysed data were downloaded on November $18^{\text {th }}, 2018$.

Data quality testing is based on an analysis of the differences between mirror data or asymmetries. Eurostat (2017a, 2017b) proposes to use the 'general' asymmetry index. 
What we propose instead is an approach using absolute differences between exports and mirror imports. Such an approach allows for the cumulation of all discrepancies and prevents the balancing of positive and negative differences. All discrepancies are thus taken into account. The authors' indicator is called the 'aggregated' data asymmetry index (mirror data quality index) and is written as:

$$
{ }_{Z} W_{E^{d}}^{P L, U E}=\frac{\sum_{i=1}^{n}\left|E_{P L, B_{i}}^{d}-I_{B_{i}, P L}^{d}\right|}{K}
$$

where:

$E_{P L, B_{i}}^{d}-$ declared value of dispatches (supply) from Poland to country $B_{i}$,

$I_{B_{i}, P L}^{d}-$ declared value of acquisitions by country $B_{i}$ delivered from Poland (mirror data),

$K=\sum_{i=1}^{n} \frac{E_{P L, B_{i}}^{d}+I_{B_{i}, P L}^{d}}{2}$,

$\mathrm{d}=1, \ldots, 76,78, \ldots, 97$ - combined nomenclature chapter's number.

The aggregate index takes values from the range from 0 to 2 . The higher its value, the lower the quality of the analyzed data.

It is worth noting that a measure constructed this way does not favour the chapters with the highest turnover, which is a feature of the absolute measure of discrepancy (understood as the sum of differences between exports and mirror imports). In order to confirm this hypothesis, for every year under consideration the values of Pearson correlation coefficients between the size of ICS within distinct nomenclature chapters and the sum of absolute differences between ICS and mirror ICA were measured. On the other hand, we have also calculated correlation coefficients between the size of ICS and the value of the index of data quality (1) (cf. Table 1). Figure 2 shows the relationship between the ICS and the sum of differences in export volumes (part a) and the index of data quality in relation to ICS volumes (part b) in 2017.

Table 1. Correlation between intra-Community supplies values, sums of absolute differences between mirror data, and indices of data quality in 2005, 2011, and 2017

\begin{tabular}{|l|c|c|c|}
\hline \multirow{2}{*}{ Correlation between } & \multicolumn{3}{|c|}{ Year } \\
\cline { 2 - 4 } & 2005 & 2011 & \multicolumn{1}{|c|}{2017} \\
\hline ICS and sum of absolute differences & 0.9336 & 0.8972 & 0.8978 \\
\hline ICS and index of data quality & -0.2276 & -0.2220 & -0.2795 \\
\hline
\end{tabular}


Figure 2. Dependence of the sum of the absolute differences between the ICS and the mirror ICA on the volume of ICS from Poland to EU countries in 2017 (a) and the value of the aggregated index of data quality in relation to the volume of ICS in 2017 (b)

a)

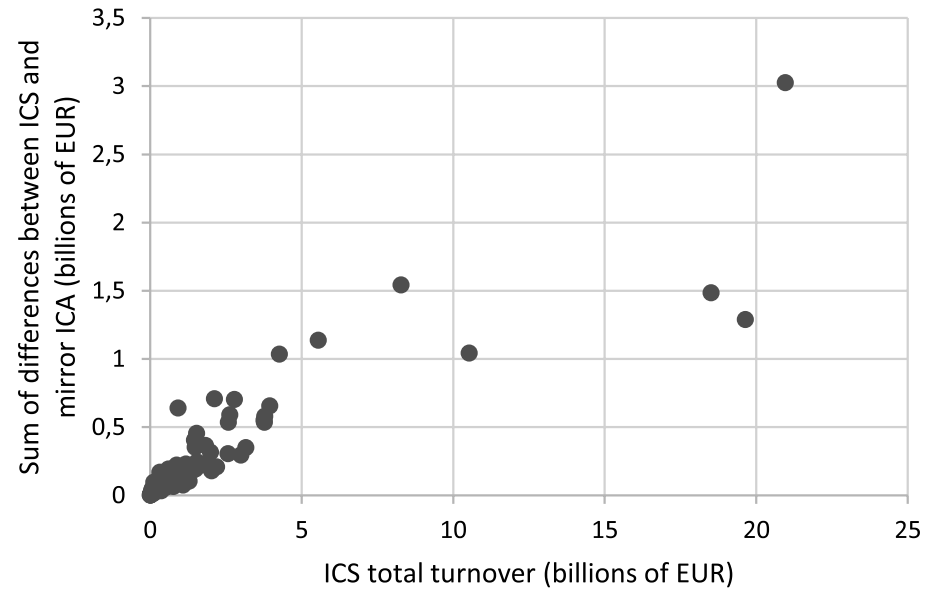

b)

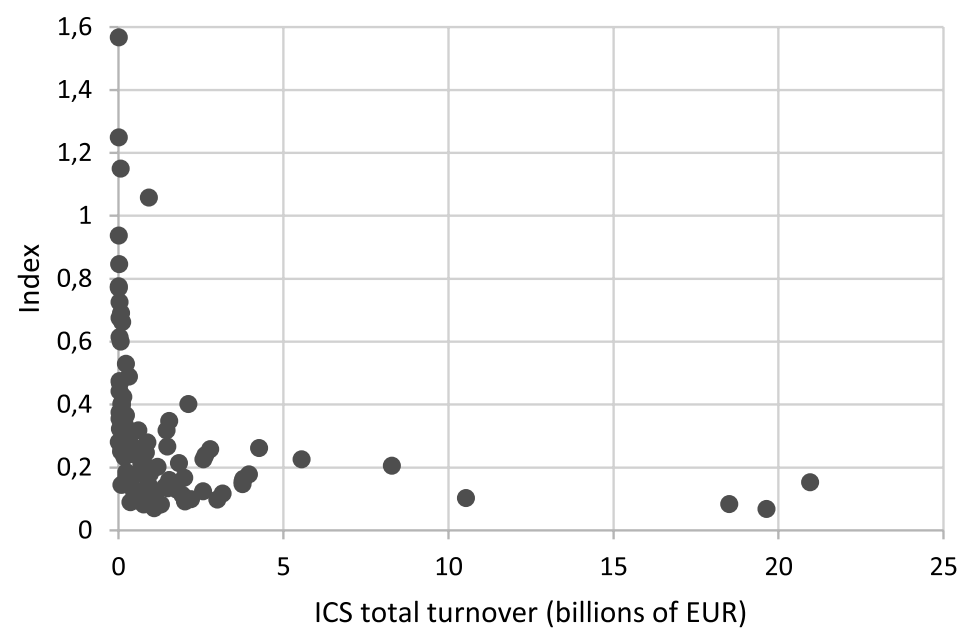

Source: own study.

Previous research by the authors has proven that such relations between total sums of ICS, sums of absolute differences and data quality indices also hold true for data divided by country of trade partner.

For each CN chapter, an aggregated data asymmetry index (1) was calculated for the years 2005, 2011 and 2017. CN chapters were then ranked according to the value of the index in each year. This resulted in joint rankings of $\mathrm{CN}$ chapters 
according to the quality of ICS mirror data in those years. Such a compilation shows how the quality of each chapter's data has changed in relation to other chapters.

\section{Quality of data on Poland's intra-Community supplies by $\mathrm{CN}$ chapter - research results}

The data used in the study were the values (in EUR) of Polish exports of goods to EU countries by $\mathrm{CN}$ chapters. In order to assess the quality of data on Poland's trade in goods with EU member states, indices of data quality between Polish exports and mirror imports for each chapter of the CN in 2005, 2014 and 2017 were calculated. Then rankings were drawn up based on the determined values of indices. Comparison of three rankings on one chart allows us to assess the dynamics of data quality in individual chapters. Due to the fact that a large number of sections were compared, Figures 3 and 4 show only a selection of them. Namely:

- 5 chapters with the highest data quality in 2017 (chapters: 84, 29, 3, 82, 85),

- 5 chapters with the lowest data quality in 2017 (chapters: 97, 89, 93, 14, 50),

- 5 chapters with the highest increase in the data quality ranking (chapters: 82 - which has already been identified as one of the top five, 61, 30, 10, 96),

- 5 chapters with the highest drop in the data quality ranking (chapters: 15 , $51,53,37,55)$.

Table 2 presents a summary of the indicated chapters together with the descriptions of product groups they contain.

The first group includes machines and equipment (including electrical ones) and tools, i.e. industrial products in general, as well as organic chemistry products and fish. These are broad categories, high turnover translates into a relatively small share of data discrepancies.

Among the worst in terms of data quality are works of art, ships, weapons, plaiting products (for example, bamboos, rattans, reeds) and vegetable products not included in chapters 6 to 13, followed by products of silk. In general, these are relatively small categories, often recorded only on one side of the transaction. Low scores in these product groups are influenced by a fairly large number of countries for which there was a high asymmetry in the submissions or a lack of submissions by one of the parties. This is also due to different reporting regimes in different countries for certain product groups (e.g. weapons are such a category). 
Table 2. Selected CN chapters in all four categories

\begin{tabular}{|c|c|}
\hline \multicolumn{2}{|r|}{ High data quality in 2017} \\
\hline Chapter 84 & Nuclear reactors, boilers, machinery and mechanical appliances; parts thereof \\
\hline Chapter 29 & Organic chemicals \\
\hline Chapter 3 & Fish and crustaceans, molluscs and other aquatic invertebrates \\
\hline Chapter 82 & Tools, implements, cutlery, spoons and forks, of base metal; parts thereof (...) \\
\hline Chapter 85 & $\begin{array}{l}\text { Electrical machinery and equipment (...), television image and sound recorders and reproducers, } \\
\text { and parts and accessories of such articles }\end{array}$ \\
\hline \multicolumn{2}{|r|}{ Low data quality in 2017} \\
\hline Chapter 97 & Works of art, collectors pieces and antiques \\
\hline Chapter 89 & Ships, boats and floating structures \\
\hline Chapter 93 & Arms and ammunition; parts and accessories thereof \\
\hline Chapter 14 & Vegetable plaiting materials; vegetable products not elsewhere specified or included \\
\hline Chapter 50 & Silk \\
\hline \multicolumn{2}{|r|}{ High position increase in the data quality ranking } \\
\hline Chapter 82 & Tools, implements, cutlery, spoons and forks, of base metal; parts thereof (...) \\
\hline Chapter 61 & Articles of apparel and clothing accessories, knitted or crocheted \\
\hline Chapter 30 & Pharmaceutical products \\
\hline Chapter 10 & Cereals \\
\hline Chapter 96 & Miscellaneous manufactured articles \\
\hline \multicolumn{2}{|r|}{ High position decrease in the data quality ranking } \\
\hline Chapter 15 & Animal or vegetable fats and oils and their (...) products; (...) edible fats; (...) waxes \\
\hline Chapter 51 & Wool, fine or coarse animal hair; horsehair yarn and woven fabric \\
\hline Chapter 53 & Other vegetable textile fibres; paper yarn and woven fabrics of paper yarn \\
\hline Chapter 37 & Photographic or cinematographic goods \\
\hline Chapter 55 & Man-made staple fibres \\
\hline
\end{tabular}

Source: Regulation (2018).

Stars of the ranking are tools, clothing, pharmaceuticals, cereals, various industrial articles. It is in these groups of goods that the greatest progress in data quality has taken place over the last 12 years. This may have happened as a result of some kind of market cleaning and takeover by large entities that report transactions correctly, both on the ICS and ICA side in the partner countries. However, this fact would require in-depth analysis at the transaction level.

The last of the groups in Table 2, are falling stars - they were top ranked once, bit their ranking dropped significantly: fats and oils, wool, vegetable textile fibres, photographic materials, and man-made staple fibres - three of which come from a common CN section (Textiles and textile articles). Quality of data on trade for these groups of goods has dropped from 57 to 64 positions for each of the groups 
over twelve years. One of the possible reasons may be the large number of small traders in those categories of goods that are below the statistical threshold or do not comply with the reporting obligation. Again, an in-depth analysis may provide an explanation.

Figure 3. Values of data quality indices for selected $19 \mathrm{CN}$ chapters in 2005, 2011 and 2017 (five worst are labelled)

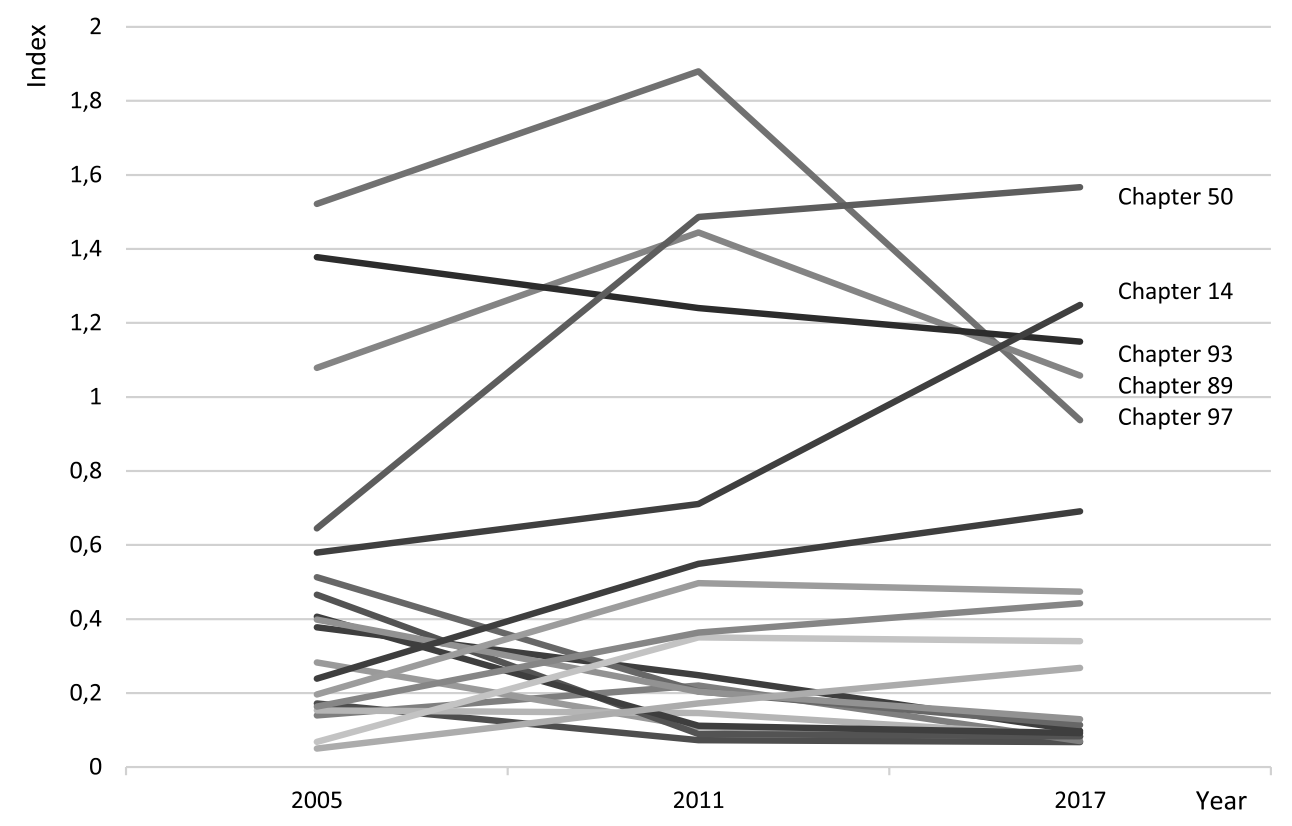

Source: own study.

Figure. 4 shows the rankings for the same 19 chapters in each of the analyzed years (the best group trajectories and worst ones are drawn with solid lines, rising stars - dotted lines, falling stars - dashed lines). We can observe the most spectacular trajectories for raising and falling stars. It can also be seen that there exist a group of chapters of low data quality that has not improved over the period under consideration (chapters $89,93,97$ ). 
Figure 4. Positions in the ranking according to the quality of data for selected $19 \mathrm{CN}$ chapters in 2005, 2011 and 2017.

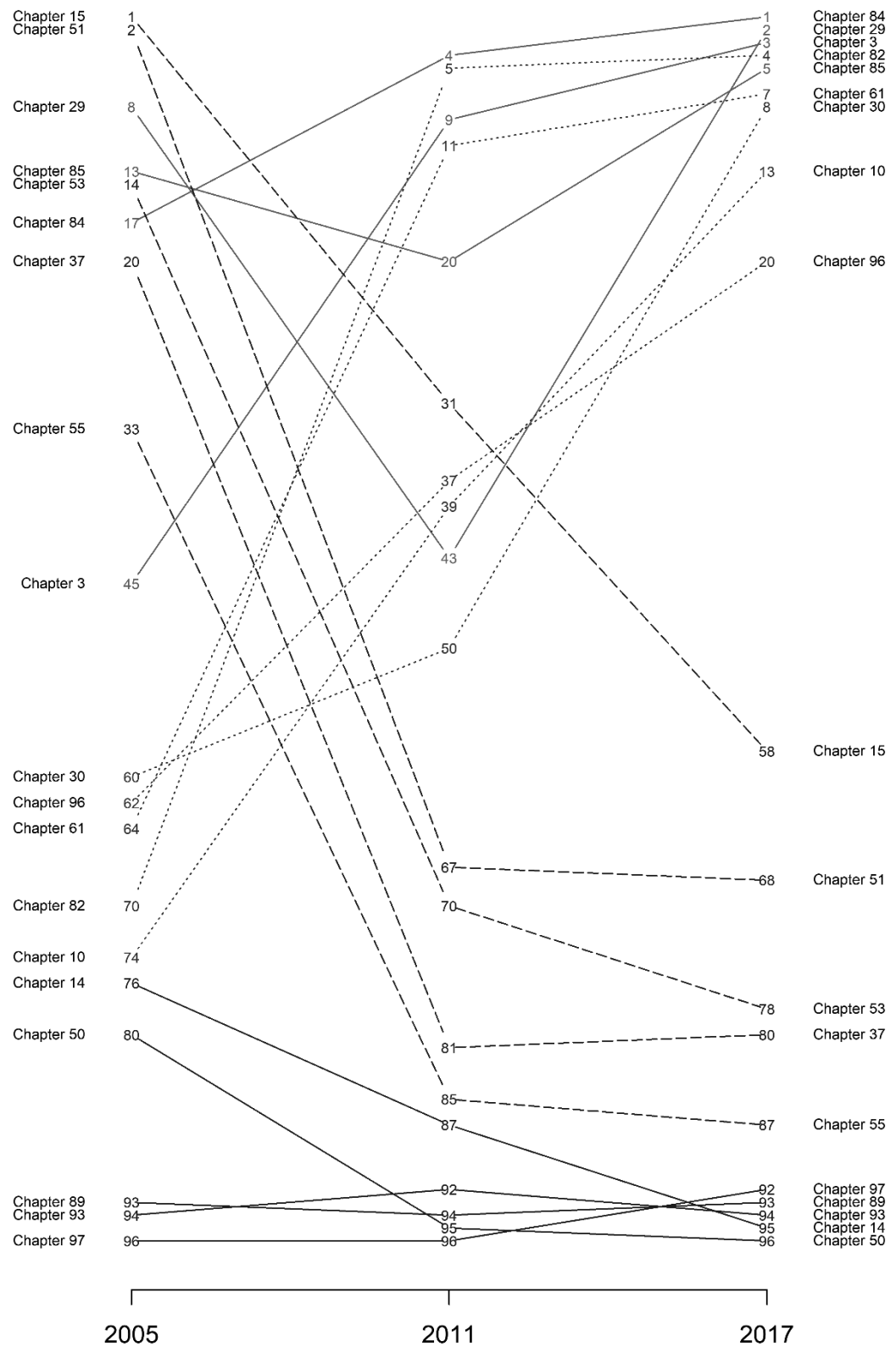

Source: own study. 


\section{Conclusions}

In foreign trade statistics, the comparability of data derived from the public statistics of different countries is extremely important. It is emphasized as a quality criterion in EU legal acts. Therefore, the authors decided to carry out an analysis of the quality of data on Poland's intra-Community trade in goods by $\mathrm{CN}$ chapters. The study was conducted for the years 2005, 2011 and 2017 to observe changes over time. The values of the data quality indices and the ranking based on them proved to be unstable over time, although the weakest positions in the ranking were more stable. Apparently, there exist chapters of combined nomenclature which are consistently characterized by low data quality and, as such, pose a challenge to official statistics services and are of interest to researchers.

\section{References}

Baran, P., Markowicz, I. (2018a). Analysis of intra-Community Supply of Goods Shipped from Poland. Socio-Economic Modelling and Forecasting, 1, 12-21.

Baran, P., Markowicz, I. (2018b). Behavioral Economics and Rationality of Certain Economic Activities. The Case of Intra-Community Supplies. In: K. Nermend, M. Łatuszyńska (Eds.), Problems, Methods and Tools in Experimental and Behavioral Economics (pp. 285-299). Cham: Springer.

Regulation (2018). Commission implementing regulation (EU) 2018/1602 of 11 October 2018 amending Annex I to Council Regulation (EEC) No 2658/87 on the tariff and statistical nomenclature and on the Common Customs Tariff (12.12.2018).

Domiter, M. (2008). Eksport w doktrynie i polityce gospodarczej na tle procesów liberalizacyjnych i integracyjnych. Wrocław: Wydawnictwo Akademii Ekonomicznej we Wrocławiu.

Drzewoszewska N., Pietrzak M.B., Wilk J. (2013). Grawitacyjny model przepływów handlowych między krajami Unii Europejskiej w dobie globalizacji. Roczniki Kolegium Analiz Ekonomicznych, 30, 187-202.

Eurostat (2017a). Compilers Guide on European Statistics on International Trade in Goods, 2017 Edition. Manuals and Guidelines. Luxembourg: Publications Office of the European Union. Retrieved from http://ec.europa.eu/eurostat (2.06.2018).

Eurostat (2017b). National Requirements for the Intrastat System. 2018 Edition. Luxembourg: Publications Office of the European Union. Retrieved from http://ec.europa.eu/ eurostat (2.06.2018).

Eurostat (2018). International Trade in Goods. Retrieved from https://ec.europa.eu/eurostat/ statistics-explained/index.php?title=International_trade_in_goods (2.06.2018).

GUS (2017). Handel zagraniczny. I-IX $2017 r$ r. Retrieved from http://stat.gov.pl/obszarytematyczne/ceny-handel/handel/handel-zagraniczny-i-ix-2017-r-,5,14.html (2.06.2018). 
GUS (2018). Handel zagraniczny. Statystyka lustrzana i statystyka asymetrii. Warszawa.

Misztal, P. (2010). Hipoteza wzrostu gospodarczego stymulowanego przez eksport. Doświadczenia Polski w okresie 1997-2009. In: J. Misala (Ed.), Teoria i polityka wzrostu gospodarczego - osiagnięcia $i$ doświadczenia (pp. 37-51). Warszawa: Wydawnictwo CeDeWu.

Regulation (2004). Regulation (EC) No 638/2004 of the European Parliament and of the Council of 31 March 2004 on Community statistics relating to the trading of goods between Member States and repealing Council Regulation (EEC) No 3330/91. Retrieved from https://eur-lex.europa.eu (5.06.2018).

Regulation (2009). Regulation (EC) No 223/2009 of the European Parliament and of the Council of 11 March 2009 on European statistics. Retrieved from https://eur-lex.europa.eu (5.06.2018).

Topolewski, Ł. (2014). Wymiana handlowa a wzrost gospodarczy. Studia i Prace WNEiZ US, 37/2, 347-356.

\section{ASYMETRIA DANYCH LUSTRZANYCH DOTYCZĄCYCH POLSKICH DOSTAW WEWNĄTRZWSPÓLNOTOWYCH - ZMIANY W CZASIE}

\section{Streszczenie}

Badania dotyczące handlu między krajami Unii Europejskiej opierają się na danych z systemu Intrastat. Informacje o transakcjach handlowych są rejestrowane na podstawie deklaracji podmiotów zajmujących się wywozem lub przywozem towarów z UE. Są to dane lustrzane, gdyż gromadzi się je z jednej strony jako wartości wywozu towarów, a z drugiej strony - jako wartości przywozu. Dane lustrzane powinny się zatem pokrywać, ale tak nie jest. Przedmiotem badania są polskie dostawy wewnątrzwspólnotowe według grup towarowych. Celem artykułu było utworzenie rankingów działów towarowych CN polskiego wywozu do UE w latach 2005, 2011 i 2017 oraz ich porównanie. Wykorzystując zaproponowane miary rozbieżności danych, oceniono jakość informacji statystycznych o wewnątrzwspólnotowym obrocie towarowym Polski według działów CN.

Słowa kluczowe: wewnątrzwspólnotowy handel Polski, działy CN, jakość danych Kody JEL: F14, C10, C82

\section{Cytowanie}

Markowicz, I., Baran, P. (2019). Asymmetries in mirror data on Polish intra-Community supplies - changes over time. Studia i Prace WNEiZ US, 55, 55-66. DOI: 10.18276/ sip.2019.55-05. 